https://doi.org/10.30836/igs.1025-6814.2020.1.196975

UDC 551.79:(562.5+563.12)

V.V. YANKO, Dr. Sci. (Geol. \& Mineral.), Prof., Head of Department,

Department of Physical and Marine Geology, Odessa I.I. Mechnikov National University,

2, Shampansky Per., Odesa, Ukraine, 65058

E-mail: valyan@onu.edu.ua

T.O. KONDARIUK, Assoc. Prof.,

Department of Physical and Marine Geology, Odesa I.I. Mechnikov National University,

2, Shampansky Per., Odesa, Ukraine, 65058

E-mail: tanya_kondaruk@ukr.net

\title{
ORIGIN AND TAXONOMY OF THE NEOPLEISTOCENE-HOLOCENE PONTO-CASPIAN BENTHIC FORAMINIFERA
}

This paper outlines the origin and taxonomy of the Neopleistocene-Holocene Ponto-Caspian benthic foraminifera for their future use in stratigraphy, geological history, and paleogeographic reconstructions, including water exchange between the neighboring basins. It is shown that the Caspian foraminiferal fauna is shallow, highly endemic (92\%), and contains many (61\%) agglutinated species and subspecies. The Pontic foraminiferal fauna is characterized not only by insignificant endemism (0.6\%) at the species and subspecies level, but also by a large number (83\%) of Mediterranean and Atlantic (mainly boreal) forms. All Pontic (Azov-Black Sea) foraminifera are shallow, most probably due to the shallowness of the Bosphorus or any other strait that connected the Pontic and Mediterranean basins to each other. The particular group of the Ammoniidae-Elphidiidae creates a unique image of the Ponto-Caspian foraminiferal assemblages and indicates a tendency of forming foraminiferal fauna from a limited number of shelf genera of the southern genesis Ammonia, Elphidium, and Porosononion typical for the southern closed and semi-closed seas. The low number of high rank taxa (orders) is a result of the low salinity of the Ponto-Caspian and its restricted connection to the open ocean. The main concept of the origin and taxonomic peculiarities of the Ponto-Caspian benthic foraminifera is as follows. The foraminiferal fauna of the Caspian Sea originated largely from the Tethys and Eastern Paratethys. They evolved in a basin that was isolated from the World Ocean for a long time. The foraminiferal fauna of the Black Sea has a Mediterranean-Atlantic-Caspian origin. It is younger when compared to the Caspian fauna, and is characterized by much smaller evolutionary transformations, but much higher taxonomic diversity. The foraminiferal fauna of the Ponto-Caspian is formed by representatives of a limited number of euryfacies orders (Ammodiscida, Astrorhizida, Ataxophragmiida, Buliminida, Lagenida, Miliolida, Rotaliida) characteristic of the internal and marginal seas and their specific hydrological regime.

Keywords: autochthons; allochthons; endemics; Mediterranean immigrants; Caspian immigrants; Paratethys relics.

\section{Introduction}

During the Tertiary, the Paratethys Sea covered the north region of the Alps from Central Europe to the Aral Sea in Western Asia. From the Pliocene epoch onward (5 million years ago), the Paratethys became progressively shallower and was subdivided into several inland seas that were at times completely separated from each other. Many of these would disappear before the start of the Pleistocene, but today, only the Ponto-Caspian basins remain.
The Ponto-Caspian is defined here as a chain of intercontinental basins that encompasses the Caspian, Pontic (Black, Azov seas, the Kerch Strait), the Manych Valley, and their coasts. During the Quaternary, the Black Sea was repeatedly connected with the Caspian Sea via the Manych spillway as well as with Mediterranean Sea through the Bosphorus or Izmit Bay-Sapanca Lake-Sakarya Valley [Kerey et al., 2003] (Fig. 1). This predetermined environmental conditions and hydrolo-

C i t a t i o n: Yanko V.V., Kondariuk T.O. Origin and taxonomy of the Neopleistocene-Holocene Ponto-Caspian benthic foraminifera. Geological Journal. 2020. № 1. C. 17-33. https: doi.org/10.30836/igs.1025-6814.2020.1.196975 


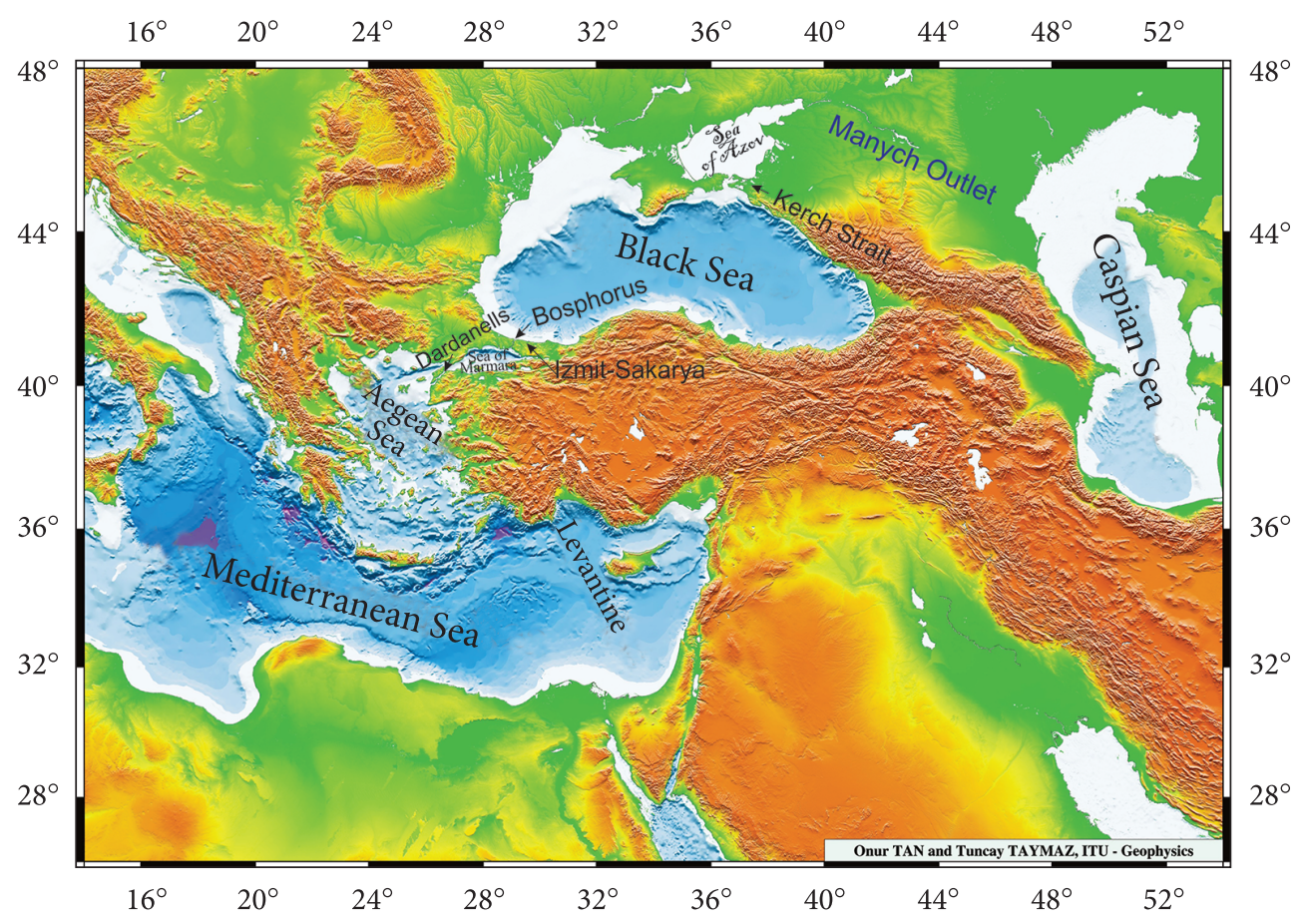

Fig. 1. The Ponto-Caspian with the Manych Spillway (blue line) on the northeast, and the Bosphorus Strait and IzmitSakarya Straits on the southwest that from time to time connected the Pontic basin with the Caspian Sea and Mediterranean Sea, respectively, and served as a passage for organisms to enter the Pontic basin (modified after O. Tan and T. Taymaz, Istanbul Technical University)

gic regimes of the Ponto-Caspian basins imposed specific impacts on diverse biological populations, including foraminifera.

There are many past/present geological projects in the "Ponto-Caspian Corridors". The most recent geological projects include "INQUA 501 "CaspianBlack Sea-Mediterranean Corridor during the last 30 ky: Sea level change and human adaptive strategies" (2005-2011), IGCP 521 "Black Sea-Mediterranean Corridor during the last $30 \mathrm{ky}$ : sea level change and human adaptation" (2005-2011), IGCP 610 "From the Caspian to Mediterranean: Environmental Change and Human Response during the Quaternary" (2013-2018), PRIDE (Pontocaspian RIse and Demise) (2015-2019). INQUA Focus Group SACCOM: 1709F "Ponto-Caspian Stratigraphy and Geochronology (POCAS)" (20182020). Besides the large international projects the work was constantly carried out by Odessa I.I. Mechnikov National University, Ukraine; Prichernomorskoe State Regional Geological Enterprise "Prichernomor GRGP," Odessa; Moscow M.V. Lomonosov State University, Russia; the Institute of Geography, Russian Academy of Sciences; the Department of Marine Geology and Mineral Resources of the National Academy of Sciences of
Ukraine; P.P. Shirshov Institute of Oceanology, Russian Academy of Sciences; Avalon Institute of Applied Science, Canada; the National Institute of Marine Geology and Geoecology, Romania; the Geology Institute of the Azerbaijan National Academy of Sciences; the Museum of Natural History, Bulgaria; the Institute of Oceanology, Bulgaria; IFREMER, France; Memorial University, Canada; Lamont-Doherty Earth Observatory of Columbia University, USA; Temple University, USA; Delaware University, USA; Istanbul University and Istanbul Technical University, Turkey; Horizon 2020 PRIDE, and many others. These efforts have produced a variety of geochronological scales for the Ponto-Caspian Corridors.

Geological data obtained by past and present projects were analyzed by many scientists, such as N.I. Andrusov, A.D. Arkhangelsky, N.M. Strakhov, M.M. Zhukov, V.M. Muratov, L.A. Nevesskaya, P.V. Fedorov, G.I. Popov, A.A. Svitoch, V.A. Zubakov, E.F. Shnyukov, A.L., P.F. Gozhik, Chepalyga, F.A. Shcherbakov, A.B. Ostrovsky, N. Panin, V. Yanko-Hombach, T.A. Yanina, A. Mamedov, P.N. Kuprin, V.M. Sorokin, E. Aliyeva, G. Oaie, M. Melinte, I. Motnenko, G. Karaivan, Ya.A. Izmailov, S.A. Nesmeyanov, I.P. Balabanov, N.V. Esin, M. Filipova- 
Marinova, D. Petko, G. Lericolais, R. Hiscott, A. Aksu, P. Mudie, W.B.F. Ryan, I. Buynevich, E.P. Larchenkov, R. Martin, M.N. Çağatay, H. Koral, Y. Yılmaz, O. Algan, W. Krijgsman, and many others.

A stratigraphic scale for the Ponto-Caspian region was developed based on mollusks [e.g., Nevesskaya, 1965; Fedorov, 1978; Yanina, 2014], foraminifera [Yanko, 1989, 1990; Yanko-Hombach, 2007, 2014, 2017], mollusks and ostracoda [Krijgsman et al., 2019]. This, in turn, enabled reconstruction of the hydrological regime of the basins as well as an approximate correlation of major events in this region with those in the Mediterranean Sea and the World Ocean. Scientists more or less agree to the following correlation between stratigraphic units and MISs in the Black Sea, Caspian, and Mediterranean regions, respectively: Bakinian-Chaudian-Sicilian (MIS 19-13), Early Khazarian-Old Euxinian + Uzunlarian-Paleotyrrenian (MIS 11-7), Late Khazarian-KarangatianTyrrenian (MIS 5), Khvalynian-Neoeuxinian- Grimaldian (MIS 4-2), and Novocaspian-Chernomorian-Verzilian (MIS 1). However, many questions remain unsolved. For example, there is no unanimous opinion on the correlation of local horizons not only with each other but with MISs as well. This is because the absolute age of the sediments in the holo-, lecto-, neo-, hypo-, para-, and boundary stratotypes varies depending on the method used, e.g., 230U/Th, thermolumi-nescence, etc. [Zubakov, 1986] and requires revision. There is no unanimous opinion on the number of transgressive and regressive stages and their amplitude in certain geological epochs.

Because of this lack of agreement, some researchers are trying to use alternative methods to clarify the order of events, thereby introducing even more confusion. For example, [Badertscher et al., 2011] used oxygen isotope $(\delta 18 \mathrm{O})$ signatures in stacked speleothems from Sofular Cave in northern Turkey to propose that the Black Sea and Mediterranean connection as well as that between the Black Sea and Caspian have been open for a greater number of periods than previously thought. In particular, Caspian-Black Sea connections opened at least seven times, while MediterraneanBlack Sea connections occurred at least twelve times since $670 \mathrm{ka} \mathrm{BP}$. However, [Yanko-Hombach and Motnenko, 2011] respond that if the data of [Badertscher et al., 2011] are correct, we would see corresponding alternations of faunal assemblages in coeval age sequences exposed in stratotypes of the Kerch and Taman peninsulas, and the Caucasian coast. However, foraminifera show that the Caspian-Black Sea and Mediterranean-Black Sea connections existed four and six times, respectively, since the Matuyama-Brunhes reversal (i.e., the last $780 \mathrm{ka}$ ), and in most cases, these connections did not occur synchronously with those of Badertscher et al. In summary, despite over 150 years of intensive field studies and interpretative research, there is no up-to-date high-resolution stratigraphic scale for the Corridor as well as exact timing of the water exchange between adjacent basins.

This paper focuses on the evolutionary patterns of benthic foraminifera, with the main accent being on their origin and taxonomy, in order to provide an outlook on the currently existing geochronological scales and demonstrate the number, time, and direction of MS and CS water intrusions into the BS during the Pleistocene. No similar work has been undertaken so far by any group of scientists, except for our own. The present format of the paper is insufficient for us to provide indepth insight into this subject, but this insight will be made available elsewhere soon (Yanko-Hombach, in preparation).

The value of benthicforaminifera for stratigraphy and paleoenvironmental reconstruction is well known. These organisms are ubiquitous in marine environments and have tremendous taxonomic diversity; therefore, they have the potential for diverse biological responses to environmental changes. Their tests are readily preserved in sediments and are small, widely distributed, hardshelled (to leave a post-mortem record), small (for robust statistics), and short-lived. It is very important for the Ponto-Caspian, which experienced frequent changes in salinity, that these marine organisms being sufficiently diverse are very sensitive to salinity variations (Fig. 2).

To be successful, the application of benthic foraminifera to high-resolution stratigraphy and paleoenvironmental reconstructions requires precise taxonomic identification of species and their further integration into the general system of foraminifera. As of today, foraminiferal taxonomy relies largely on a phenetic species concept [e.g., Loeblich and Tappan, 1988] that classifies foraminifera by their morphological similarities, which can also be caused by environmental variations. As a consequence, it is often difficult to make a decision whether morphological 


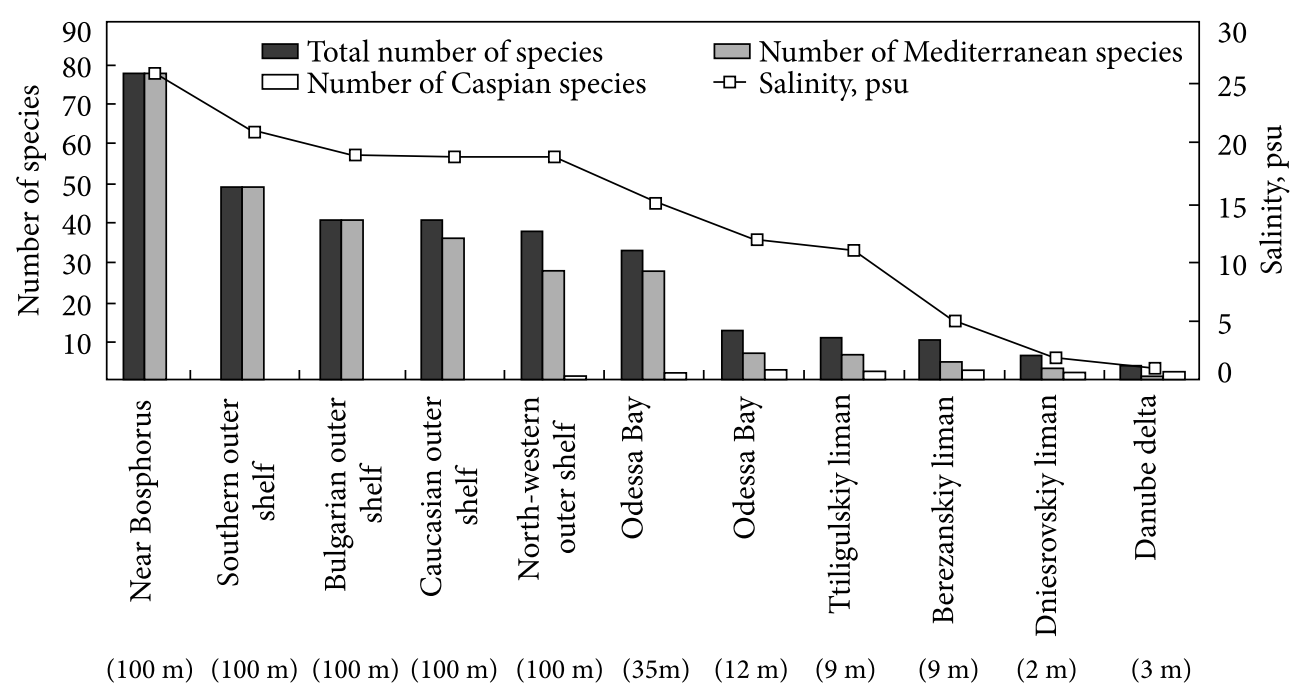

Fig. 2. Increase in the number of foraminiferal species with increasing salinity in various areas of the Black Sea (average depths of sampling areas shown in parentheses) [Yanko-Hombach, 2007]

variations are genotypic or ecophenotypic. Classifying foraminifera by morphological criteria only may lead to an appearance of species with wide geographic and stratigraphic distribution, e.g., Ammonia becarrii (Linné). To avoid this, a complex analysis of various characteristics of foraminiferal tests in conjunction with environmental preferences of a given taxon is needed. The molecular concept [e.g., Holzmann, 2000] can open new perspectives for the taxonomy of recent foraminifera because molecular systematics will allow clear definitions of existing taxa and investigation of hidden genetic subdivisions (sibling species). However, as of today, it is in the early stages of its development, meaning that no sufficient data bank has yet been established.

As a part of the study, a direct comparison of the Ponto-Capsian low rank taxa (species and subspecies) with the original collections of d'Orbigny, Schlumberger, and Le Calvez in the Museum of Natural History, Paris; L. Maisuradze in the Institute of Paleobiology in Tbilisi; and A.K. Bogdanowicz in Krasnodar was performed by the first author in various stages of the research. The generic classification of Orlov (1959) and Loeblich and Tappan (1992) has been used for classification of high rank taxa. The Reference Collection of PontoCaspian Quaternary foraminifera is stored at the Paleontological Museum of Odessa I.I. Mechnikov National University, Ukraine (No 3906). At present, 165 low rank taxa are on file [Yanko, 1989].

\section{Study area, material and methods}

The study area includes the Ponto-Caspian and adjacent basins [e.g., Yanko, 1989, 1990a,b; Yanko et al., 1998; Yanko-Hombach, 2007; Yanko-Hombach et al., 2014a, 2017]. Foraminifera along with geological properties of sediments were studied by the first author in 112 coastal outcrops, many of which are Ponto-Caspian stratotypes [Yanko, 1989, 1990a], 56 boreholes [Yanko and Gramova, 1990] and $\sim 4000$ gravity/vibracores from the Black and Caspian seas; 18 boreholes from the Bosphorus Strait, the Sea of Marmara [e.g., Yanko et al., 1999], Izmit Gulf and Sakarya [Meriç et al., 1995] and supplemented by hundreds of ${ }^{14} \mathrm{C},{ }^{230} \mathrm{Th} / \mathrm{U}$, and Electron Spin Resonance (ESR) dates. Lately, studied material was supplemented by new data obtained in course of the FR6 EU HERMES and EU BLACK SEA ERA.NET-WAPCOAST scientific cruises performed on 19-27 September 2008 and 3-7 May 2012 using the Ukrainian "Vladimir Parshin" and Romanian "Mare Nigrum" research vessels, respectively.

The HERMES cruise was carried out in the northwestern part of the Western Black Sea depression within a depth range of 70-905 m. Fortysix stations at water depths of 71-905 m were sampled by grab and gravity core. The WAPCOAST cruise was performed in the northwestern part of the Black Sea shelf adjacent to the Romanian part of the Danube delta at water depths 5-81. Seventeen stations were sampled by grab and multicorer. In both cruises, at the majority of the stations, the salinity, dissolved oxygen, and temperature of bottom water were measured. Water and sediment samples for hydrochemical, lithological, geomechanical, mineralogical, gasgeochemical, organic car- 
bon, as well as meiobenthos (e.g., Foraminifera, Ostracoda, Nematoda) were collected and investigated in the laboratory by respective methods [Yanko et al., 2017; Yanko-Hombach et al., 2017; Kondariuk, 2018].

The Eastern Mediterranean foraminifera of the Israeli offshore area and Iskenderun Bay, Turkey, were investigated in 425 samples recovered by gravity core, box-corer, and grab and studied as part of the international AVICENNE project [Yanko et al., 1998, 2006].

At each marine station and outcrop, the total assemblage was determined and expressed as the number of tests (abundance) per $50 \mathrm{~g}$ of dry sediment as described in [Yanko, 1989, Yanko \& Troitskaya, 1987, and Yanko et al., 1998]. Large samples were randomly split with a splitter into subsamples. At least 300 specimens, whenever possible, were picked by hand under a binocular microscope. Broken foraminiferal tests, fragments and old tests (re-crystallized, worn down, filled with sediments) were considered to be reworked and excluded from the analysis.

All specimens were morphologically examined and taxonomically identified. Examples of all species were imaged using Scanning Electron Microscopy (SEM) at Tel Aviv University, Tel Aviv, Israel, Museum of Natural History, Paris, and University of Manitoba, Winnipeg, Canada. Particular attention was given to the tests with morphological abnormalities reflecting environmental/paleoenvironmental stress [Yanko et al., 1998; Kondariuk, 2018].

The methods used in taxonomic identification are described in [Yanko, 1989]. They include: a complex study of external and internal test morphology, wall ultrastructure, and chemical content of the tests taking into account di- and trimorphism in selected taxa (Ammonia, for example). Thin cross-sections and molds of the tests were prepared for the majority of the Rotaliida to define their taxonomic position.

Certain approaches were undertaken to gain insight into the origin and evolutionary development of the Ponto-Caspian benthic foraminifera during the last 1.8 Ma [Yanko, 1989, 1990]: (1) Identification of allochthonous species that moved into the Ponto-Caspian from adjacent basins (external allochthons) or from one part of the PontoCaspian to another (internal allochthons) at different times with determination of their pathways and direction of migration. (2) Differentiation of ancient, new, and newest autochthonous species the ancient allochthons inhabited previously the Eastern Paratethys [Bogdanowich, 1947; Maisuradze, 1971, 1980; Maisuradze, Koiava, 2008, 2011a, 2011b], the new and newest allochthons inhabited the Eopleistocene and the Neopleistocene-Holocene basins, respectively. (3) Identification of preQuaternary relics and Quaternary endemics. (4) Identification and exclusion of reworked (Cretaceous-Pliocene) forms found practically throughout the whole Quaternary section.

\section{Results and discussion}

\section{Stratigraphy and connection with the neighboring basins}

In our work, we follow the Russian divisions of the Quaternary System, which separates the Quaternary into the Eopleistocene $(1.8-0.78 \mathrm{Ma})$, the Neopleistocene $(0.78-0.01 \mathrm{Ma})$, and the Holocene (0.01-0.0 Ma) [Zhamoida, 2004]. The boundary between the Eopleistocene and Neopleistocene coincides with the Brunhes- Matuyama Reversal (BMR), which is readily traced in both the Pontic and Caspian regions at the bottom of the Lower Chaudian and Gurian horizons, and the Apsheronian and the Bakinian horizon, respectively, and coincides with the evolutionary pattern in the development of benthic foraminifera [YankoHombach, 2014].

The Ponto-Caspian stratigraphic scale is given in Table. In the Caspian region, the Eopleistocene is represented (from bottom to top) by the Apsheronian horizon; the lower Neopleistocene by the Bakinian horizon; the middle Neopleistocene by the Khazarian horizon; the upper Neopleistocene by the Khvalynian; and the Holocene by the New Caspian horizons [Yanko-Hobach et al., 2006; Yanko-Hombach, 2014, 2017].

In the Pontic region, the Eopleistocene is represented by the Gurian horizon (at least its upper part), the Chaudian horizon that possesses at its top the Karadenizian beds corresponding to the first Pleistocene intake of Mediterranean water and fauna into the Chaudian basin; the middle Neopleistocene by the Old Euxinian and Uzunlarian horizons; the upper Neopleistocene by the Karangatian, Tarkhankutian, and Neoeuxinian horizons; and the Holocene by the Old Chernomorian (Bugazian, Kolkhidian, Vityazevian, Pontian) and Neochernomorian (Kalamitian, Egrissian, Dzeme- 
tinian, Phanagorian, Nymphaean, Korsunian, Recent) beds. Their uncalibrated ${ }^{14} \mathrm{C}$ age is given in [Martin, Yanko-Hombach, 2011, and Yanko-Hombach et al., 2011]. The sea level during the Holocene rose gradually with an oscillating mode
[Balabanov, 2007; Yanko-Hombach, 2007; YankoHombach et al., 2017; Yanko et al., 2019]. In the Holocene, no fewer than six transgressive and regressive phases in turn, complicated by smaller rhythmics, can be observed. The boundary between

Stratigraphy of the Black Sea region (without proper scale) and its connections with the Mediterranean (MS) and the Caspian (CS). Light gray = MS-BS connection; dark gray = CS-BS connection; black = BS isolation; not colored = suggested connection (after Yanko-Hombach et al., 2017)

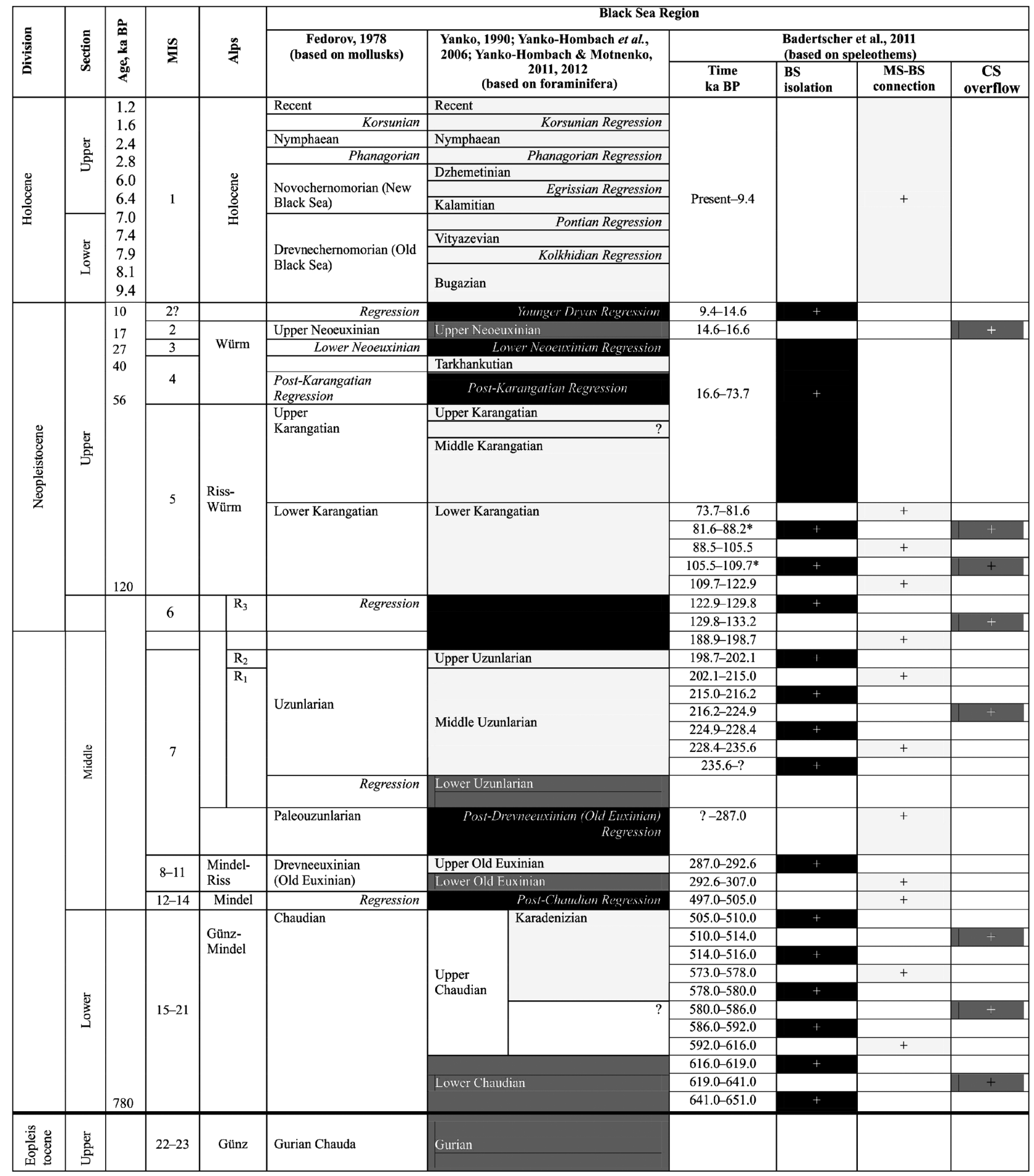


the Neopleistocene and Holocene has a ${ }^{14} \mathrm{C}$ age around 9 ka BP (uncalibrated) [Yanko-Hombach et al., 2017; Yanko et al., 2019].

The Pontic basin was connected to the Caspian in the Early Chaudian, Early Old Euxinian, Early Uzunlarian, and Late Neoeuxinian times. During these connections, Caspian foraminifera immigrated from the Caspian to the Pontic basin but not vice versa because the former was hypsometrically higher than the latter.

The Pontic basin was connected to the Mediterranean in Karadenizian, Late Old Euxinian, Middle-Late Uzunlarian, Early-Middle-Late Karangatian, Tarkhankutian, Old Chernomorian, and Neochernomorian times. The most powerful Mediterranean transgression, that increased salinity in the Pontic basin up to $33 \mathrm{psu}$, occurred in Karangatian time (MIS 5e).

During these connections, foraminiferal fauna immigrated into the Pontic basin either from the Caspian or Mediterranean basins.

\section{Taxonomy}

In total, the Ponto-Caspian foraminifera are represented by 165 low rank taxa from seven orders (Fig. 3).

Among the low rank taxa, 148 are calcareous and 17 agglutinated. There is only one planktonic species, Globoquadrina dutertrei (d'Orbigny), that is present in the Karangatian horizon only; the rest of the taxa are benthic.

\section{Origin}

The Caspian foraminifera are either endemics (88\%) or external allochthons (12\%) (Fig. 4, a). The Pontic foraminifera include Mediterranean immigrants (88\%), endemics (7\%), Caspian immigrants (5\%), and Parathetys relics (2\%) (Fig. 4, b)

\section{Caspian region}

Benthic foraminifera are represented by 17 genera that include 25 low rank taxa (Appendix 1). Among the genera, 25\% are known from the Paleozoic, $25 \%$ are from the Mesosoic, $19 \%$ are from the Paleogene, $30.4 \%$ are from the Neogene, and $0.6 \%$ are from the Quaternary. The Caspian endemics are mostly (62\%) agglutinated forms. Two genera Mayerella, Yanko 1987 and Birsteiniolla, Mayer 1974 - and 22 low taxa are endemics. The rest -

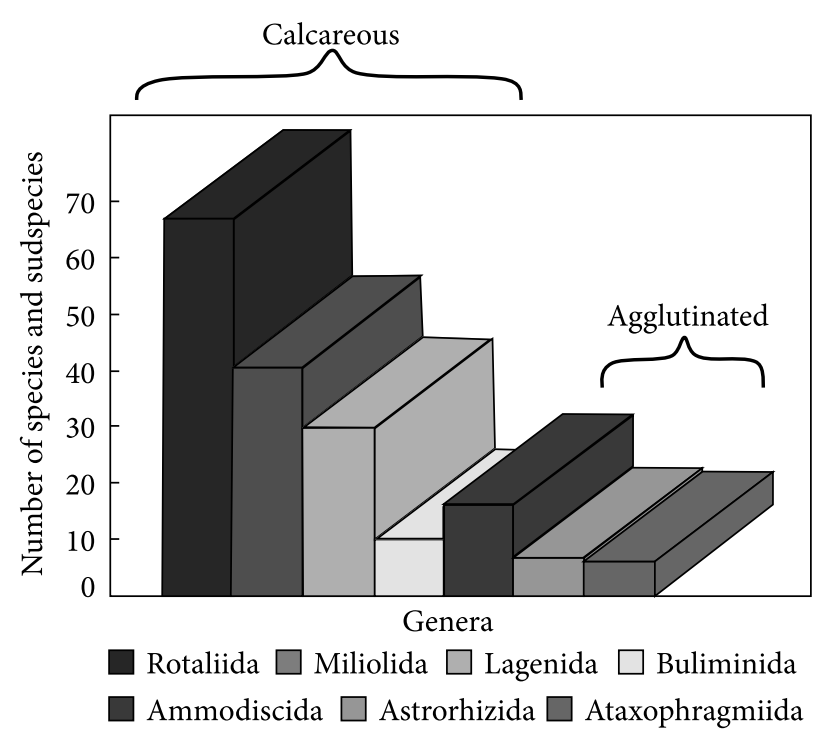

Fig. 3. Number of low rank taxa in orders of the PontoCaspian foraminifera
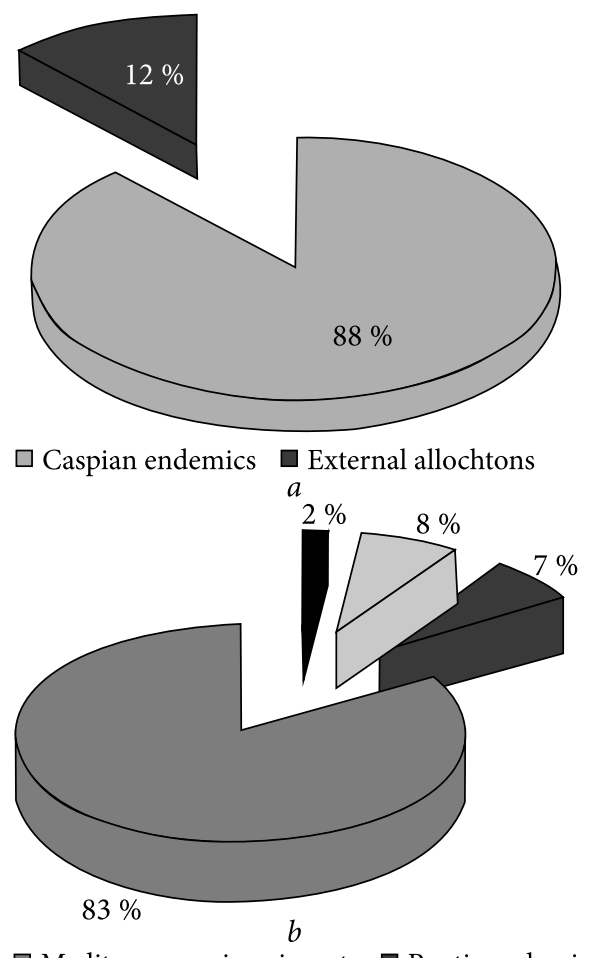

$\square$ Mediterranean immigrants $\square$ Pontic endemics $\square$ Caspian immigrants $\square$ Patathetys relics

Fig. 4. Origin of the Caspian (a) and Pontic (b) foraminifera

Elphidium gunteri Cole (present in the Eopleistocene only), Miliammina fusca (Brady), and Trichochyalus aguajoi (Bermudez) - are external allochthons well known as cosmopolitan species distributed in brackish environments around the world. Two more cosmopolitan species, Ammo- 
baculites exiguus Cushman et Brönnimann and Jadammina polystoma Bartenstein et Brand, are represented in the Caspian by subspecies. No immigrants from the Pontic basin are present. Caspian foraminiferal fauna is characterized by a high degree of endemism (92\%). Allochthonous forms have a wide dicontinious distribution. All this suggests that Caspian foraminiferal fauna is largely inherited from the Tethys/Eastern Paratethys and underwent inter-nal evolution within the basin that was isolated from the World Ocean for a very long time. This enables us to consider the Caspian region as a zoogeogra-phic province.

\section{Pontic region}

The origin and development of the Pontic benthic foraminiferal fauna is totally different from the Caspian one. Here, the benthic foraminiferal fauna is much more diverse. It is represented by 55 genera that include 154 low rank taxa (Appendix 2). There is only one agglutinated genus (Psammmosphaera) that is known from the Early Paleozoic; all other genera are known from the Cenozoic: Paleocene (Porosononion), Eocene (Elphidium), Miocene (Ammonia), Early Pliocene (Aubignyna), and Late Pliocene (Mayerella). The last genus is endemic while all others are widely distributed in the Eastern Parathetys [Maisuradze, 1980]. The dominant role $(81 \%)$ in assemblages is played by representatives of the families of Ammoniidae (Ammonia) and Elphidiidae (Porosononion and Elphidium). The genus Ammonia is represented by ten species: Mediterranean immigrants Ammonia agoiensis Yanko, A. ammoniformis (d'Orbigny), $A$. beccarii (Linné), A. compacta Hofker, A. parkinsoniana (d'Orbigny), and A. tepida (Cushman); Pontic endemics: A. novoeuxinica Yanko, A. caucasica Yanko, and A. parasovica Shchedrina and Mayer; and a Caspian immigrant A. caspica Shschedrina. Each species has own morphological affinities, stratigraphic and ecological preferences [Yanko, 1990b].

The genus Porosononion includes Porosononion subgranosus (Egger), P. martkobi Bogdnowicz, and $P$. submartkobi Yanko. The former was first described from the Miocene of Germany. It is widely distributed in the Sarmatian and Meotian of the Crimean-Caucasian region and Precarpathians [Voloshinova and Dain, 1952; Serova, 1955]. In the Quaternary, this species is represented by two subspecies, which appear in two different stratigraphic levels. Subspecies $P$. subgranosus mediterranicus Yanko is distributed from Karadenizian time up to the present. Subspecies P. subgranosus pshadicus Yanko is known from the Old EuxinianEarly Uzunlarian only. Species P. martkobi played a significant role in the Early Sarmatian [Bogdanowich, 1947]. It has three subspecies: Early Sarmatian P. martkobi martkobi Yanko and two from the Pleistocene, P. martkobi ponticus Yanko, and P. martkobitschaudicus Yanko. All Porosononion low rank taxa are holeuryhaline ( $1-26 \mathrm{psu})$ well adapted to a wide range of salinities. Species $P$. subgranosus is polytypical not only in the Quaternary but in the older geological sequences as well. For example, Sarmatian Porosononion is represented also by two subspicies $P$. subgranosus subgranosus (Egger) and P. subgranosus hyalinus (Bogd,), which difeer from each other by the amount of additional sculpture in the unbilical part of their tests.

The genus Elphidium is represented by twelve low rank taxa. Among them, there is the endemic species E. caspicum Mayer of Caspian origin. This species shows some similarities with Elphidium gunteri Cole but differs in having a smaller number of chambers, interseptal bridges in sutures, a coarser wall, and finer granulation compared to $E$. gunteri. The stratigraphic position (Sarmatian, Pliocene) and wide distribution of E. gunteri in the Eastern Paratethys [Maisuradze, 1971) enable us to consider this species as an ancestor for E. caspicum. The latter is represented by the four subspecies: Caspian E. caspicum caspicum Yanko and Pontic E. caspicum azovicum Yanko, E. caspicum karadenizum Yanko, and E. caspicum uzunlarum Yanko.

\section{Waves of migration}

There were eight major waves of foraminiferal migration into the Black Sea from the Mediterranean, corresponding to major sea-level changes in the World Ocean: (1) early Neopleistocene, (2 and 3) middle Neopleistocene, (4 and 5) late Neopleistocene, and (6 to 8) Holocene (Fig. 5).

In the course of each wave, new taxa arrived into the Pont. The fourth wave of immigration was the most powerful, bringing into the Pontic basin 54 Mediterranean low rank taxa, many of which do not live in the Black Sea today. This speaks in favor of much higher salinity than that of today 


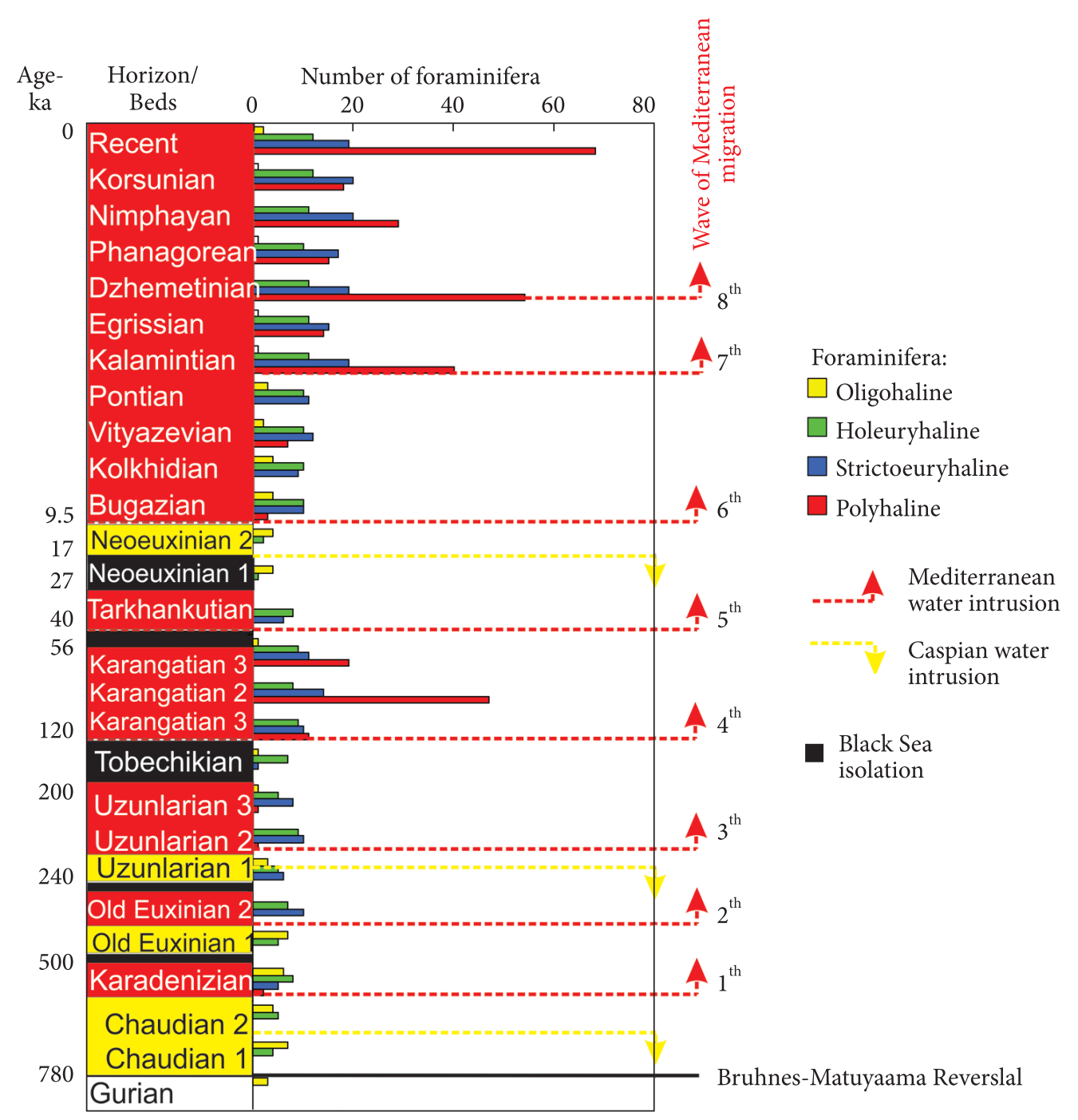

Fig. 5. Water intrusions into the Black Sea from the Mediterranean Sea and Caspian Sea during the Neopleistocene and Holocene based on benthic foraminifera

( 33 psu) for the Karangatian basin [Yanko et al., 1990]. The eighth wave of migration brought into the Black Sea 34 Mediterranean low rank taxa that live in the Black Sea today. These two waves can be used as markers in geologic sequences. The former corresponds to the Mikulino interglacial (MIS 5e) while the latter corresponds to the Holocene optimum. The other waves of immigration were somewhat weak, especially the seventh one, and corresponded to the low amplitude warmings during interglacials or at the end of glacial periods. It must be noted that many Mediterranean immigrants appeared in the Pontic basin repeatedly. However, each wave of immigration had its own specifics and, together with evolutionary transformations of foraminiferal fauna, can be used for stratigraphic and paleogeographic purposes.

\section{Conclusions}

1. The Caspian foraminiferal fauna is shallow, highly endemic (92\%), and contains many agglutinated $(61 \%)$ species and subspecies.

2. The Pontic foraminiferal fauna is characterized not only by insignificant endemism $(0.6 \%)$ at the species and subspecies level, but also by a large number (83\%) of Mediterranean and Atlantic (mainly boreal) forms. Therefore, this region can be considered as a sub-province of the Mediterranean province and a part of the boreal zone.

3. The particular group of the Ammoniidae-Elphidiidae creates a unique image of the PontoCaspian foraminiferal assemblages and indicates a tendency of forming foraminiferal fauna from a 
limited number of shelf genera of the southern genesis Ammonia, Elphidium, and Porosononion typical for the southern closed and semi-closed seas.

4. All Pontic foraminifera are shallow, most probably due to the shallowness of the Bosphorus or any other strait that connected the Pontic and Mediterranean basins to each other.

5. The low number of high rank taxa (orders) is a result of the low salinity of the Ponto-Caspian and its restricted connection to the open ocean. A similar observation was made by [Gudina, 1976] in regards to the Pleistocene northern seas.

6. The foraminiferal fauna of the Caspian Sea originated largely from the Tethys and Eastern Paratethys. It evolved in a basin that was isolated from the World Ocean for a long time.

7. The foraminiferal fauna of the Black Sea has a Mediterranean-Atlantic-Caspian origin. It is younger when compared to the Caspian fauna, and is characterized by much smaller evolutionary transformations, but much higher taxonomic diversity.

8. The foraminiferal fauna of the Ponto-Caspian comprises representatives of a limited number of euryfacies orders (Ammodiscida, Astrorhizida, Ataxophragmiida, Buliminida, Lagenida, Miliolida, Rotaliida) characteristic of the internal and marginal seas and their specific hydrological regime.

\section{Acknowledgments}

This study is a contribution to the IGCP 610 project "From the Caspian to Mediterranean: Environment change and human response during the Quaternary", INQUA International Focus Group 1709 POCAS "Ponto-Caspian Stratigraphy and Geochronology", and State Budget Theme: No. 557 "Theoretical substantiation of interaction between nature and human society in the northwestern Black Sea during the Late Pleistocene and Holocene".

\section{REFERENCES}

Badertscher, S., Fleitmann, D., Cheng, H., Edwards, R.L., Göktürk, O.M., Zumbühl, A., Leuenberger, M., Tüysüz, O., 2011. Pleistocene water intrusions from the Mediterranean and Caspian seas into the Black Sea. Nature Geoscience, no. 4, p. 236-239 (In English).

Balabanov, I.P., 2007. Holocene sea-level changes of the Black Sea. The Black Sea Flood Question: Changes in Coastline, Climate and Human Settlement. (Eds. V. Yanko-Hombach, A.S. Gilbert, N. Panin, N.P. Dolukhanov). Dordrecht: Springer, p. 711-730 (In English).

Basics of Paleontology, 1959. Vol. 1, General Part, Protozoans. (Ed. Orlov Yu. A.), Moscow: Russian Academy of Sciences, 519 p. (In Russian).

Bogdanowich, A.K., 1947. On results of foraminiferal study of Miocene foraminifera from the Crimean-Caucasian region]. (Ed. A.V. Furssenko). Microfauna of the Caucasus Oil Fields. Leningrad: Gostoptekhizdat, p. 3-33 (In Russian).

Fedorov, P.V., 1978. Pleistocene of the Ponto-Caspian Region. Proceedings of the Geological Institute of AN USSR. Issue 310. Moscow: Nauka, 178 p. (In Russian).

Gudina, V.I., 1976. Foraminifera, Stratigraphy, and Paleogeography of the Marine Pleistocene of the North of the USSR. Proceedings of the Institute of Geology and Geophysics of the Academy of Scinces of USSR, Sibirean Branch. Issue 314. Novosibirsk: Nauka, 126 p. (In Russian).

Holzmann, M., 2000. Species concept in Foraminifera: Ammonia as a case study. Micropaleontology, vol. 46, (Supplement 1: Advances in the Biology of Foraminifera), p. 21-37 (In English).

Kerey, E., Meric, E., Tunoğlu, C., Kelling, G., Brenner, R.L., Doğan, A.U., 2003. Black Sea-Marmara Sea Quaternary connections: New data from the Bosphorus, Istanbul, Turkey. Palaeogeography, Plaeoclimatology, Palaeoecology, vol. 3256, p. 1-19 (In English).

Kondariuk, T.O., 2018. Morphological deformities in benthic foraminifera tests as indicators of marine environmental stress under the freshwater runoff. Odessa National University Herald, Series Geography \& Geology, vol. 23, issue 2, p. 134-150 (In Russian).

Krijgsman W., Tesakov, A., Yanina, T. et al., 2019. Quaternary time scales for the Pontocaspian domain: Interbasinal connectivity and faunal evolution. Earth-Science Reviews, no. 188, p. 1-40 (In English).

Loeblich, A. R., Tappan, H., 1988. Foraminiferal Genera and Their Classification: New York: Van Nostrand Reinhold Company, 970 p. (In English).

Loeblich, A.R., Tappan, H., 1992. Present status of Foraminiferal Classification. Studies in Benthic Foraminifera. (Eds. Y. Takayanagi, T. Saito). Tokyo: Tokai University Press, p. 93-102 (In English).

Maisuradze, L., 1971. Sarmatian Foraminifera in Georgia. Tbilisi: Metsniereba, 118 p. (In Russian).

Maisuradze, L., 1980. On the Paleobiological History of Miocene Foraminifera in the Ponto-Caspian Basin. Tbilisi: Metsniereba, 106 p. (In Russian).

Maisuradze, L., Koiava, K., 2008. History of development of representatives of two genera - Bulimina and Bolivina in Sarmatian basin of Paratethys. Proceeding Georgian National Museum Problems of Paleobiology, vol. III, p. 60-68 (In English). 
Maisuradze, L., Koiava, K., 2011a. Biodiversity of Sarmatian Foraminifera of the Eastern Paratethys. Bulletin of the Georgian National Academy of Sciences, vol. 5, no. 1, p. 143-151 (In English).

Maisuradze, L., Koiava, K., 2011b. Meotian age, as a last stage of biodiversity of foaraminifera in the Neogene basins of Ponto-Caspian region. Proceedings of the Georgian National Museum, Natural Sciences and Prehistory Section, no. 3, p. 7-17 (In Georgian with English summary).

Martin, R.E., Yanko-Hombach (also Yanko), V., 2011. Repeated freshwater discharge events stimulated rapid sea-level change in the Black Sea during the Holocene. Geology and Geoarchaeology of the Black Sea Region: Beyond the Flood Hypothesis. (Eds. I. Buynevich, V. Yanko-Hombach, A.S. Gilbert, R. Martin). GSA Special Paper 473. Boulder, Colorado: Geological Society of America, p. 51-58 (In English).

Meriç, E., Yanko, V., Avşar, N., 1995. Foraminiferal fauna of the Quaternary sequence in the Gulf of Izmit (Herzek BurnuKaba Burun). Quaternary Sequence in the Gulf of Izmit. (Ed. E. Meriç). Istanbul: Deniz Harp Okulu Komulanliği Basimevi, p. 105-152 (In Turkish with English summary).

Nevesskaya, L.A., 1965. Late Quaternary Mollusks of the Black Sea, Their Systematics and Ecology. Trudy Paleontologicheskogo Instituta Akademii Nauk SSSR, vol. 105. Moscow: Nauka, 391 p. (In Russian).

Serova, M.Ya., 1955. Stratigraphy and foraminiferal fauna of Miocene deposits. Materials on the Biostratigraphy of the Western Regions of the Ukrainian SSR. Moscow: Gostoptekhizdat, p. 261-392 (In Russian)

Voloshinova, N.A., Dain, L.G., 1952. Nonionids, Cassidulinids, and Chilostomelids. Fossil Foraminifera of the USSR. VNIGRI Proceedings, issue 63, Leningrad: Gostoptekhizdat, 152 p. (In Russian).

Yanina, N.A., 2014. The Ponto-Caspian region: Environmental consequences of climate change during the Late Pleistocene. Quaternary International, vol. 345, p. 88-99 (In English).

Yanko-Hombach (also Yanko), V. Quaternary Foraminifera of the Caspian-Black Sea-Mediterranean Corridors: Volume 1 Ponto-Caspian Foraminifera. Monograph, in preparation, scheduled for publication in 2020-2021. Springer (In English).

Yanko-Hombach (also Yanko), V., Motnenko, I., 2011. Pleistocene water intrusions from the Mediterranean and Caspian Seas into the Black Sea: Reconstructions based on foraminifera. Abstract Volume of the Seventh Plenary Meeting and Field Trip of INQUA 501 "Caspian-Black Sea - Mediterranean corridor during the last 30 ky: Sea level change and human adaptive strategies”. (Eds. V. Yanko-Hombach, A. Gilbert). Odessa, Ukraine, August 21-28, 2011. Odessa: Astroprint, p. 187-194 (In English).

Yanko-Hombach (also Yanko), V., 2007. Controversy over Noah's Flood in the Black Sea: Geological and foraminiferal evidence from the shelf. The Black Sea Flood Question: Changes in Coastline, Climate and Human Settlement. (Eds. V. Yanko-Hombach, A.S. Gilbert, N. Panin, N.P. Dolukhanov). Dordrecht: Springer, p. 149-203 (In English).

Yanko-Hombach (also Yanko), V., 2014. Quaternary ecostratigraphy and paleogeographic reconstructions of the Caspian region based on benthic foraminifera. Proceedings of the IGCP 610 Second Plenary Conference and Field Trip: "From the Caspian to Mediterranean: Environmental Change and Human Response during the Quaternary," October 12-20, 2014, Baku, (Azerbaijan). (Eds. A.S., Gilbert, V. Yanko-Hombach). Baku: Nafta Press, p. 162-170 (In English).

Yanko-Hombach (also Yanko), V., Kondariuk, T., Motnenko, I., 2017. Benthic foraminifera indicate environmental stress from river discharge to marine ecosystems: example from the Black Sea. Journal Foraminiferal Research, no. 47, issue 1, p. 70-92 (In English).

Yanko-Hombach (also Yanko), V., Koral, H., Avşar, N., Motnenko, I., McGann, M., 2006. Geomorphological, depositional, and foraminiferal indicators of Late Quaternary tectonic uplift in Iskenderun Bay, Turkey. Postcollisional Tectonics and Magnetism in the Mediterranean Region and Asia. (Eds. Y. Dilek, S. Pavlides), GSA Special Paper 409. Boulder, Colorado: Geological Society of America, p. 591-614 (In English).

Yanko-Hombach (also Yanko), V., Schnyukov, E., Pasynkov, A., Sorokin, V., Kuprin, P., Maslakov, N., Motnenko, I., Smyntyna, O., 2017. Late Pleistocene-Holocene Environmental Factors Defining the Azov-Black Sea Basin, and the Identification of Potential Sample Areas for Seabed Prehistoric Site Prospecting and Landscape Exploration on the Black Sea Continental Shelf. Submerged Landscapes of the European Continental Shelf: Quaternary Paleoenvironments. (Eds. Flemming, N.C., Harff, J., Moura, D., Burgess, A., Bailey, G.N.). Chichester, UK: Wiley-Blackwell, p. 431-478 (In English).

Yanko-Hombach V., Gilbert A., Buynevich I., et al., 2006. Field Trip Guide. IGCP 521 Second Plenary Meeting and Field Trip, August 20-28, 2006, Odessa National University, Odessa, Ukraine, 42 pp. ISBN 966-318-569-4 (In English).

Yanko-Hombach, V. (also Yanko), Smyntyna, O.V., Kadurin, S.V., Larchenkov, E.P., Kakaranza, C.V., Kiosak, D. V., 2011. The Black Sea level change and adaptation strategy of ancient people for the last $30 \mathrm{ka}$. Geology and Mineral Resources of the World Ocean, no. 2, p. 61-94 (In Russian).

Yanko, V., 1989. Quaternary benthic foraminifera of the southern [Black, Azov, Aral, Caspian] seas: Classification, ecology, stratigraphy, geology, paleoenvironmental reconstructions. D. Sci. Thesis, Moscow State University, Moscow, 1000 p. (In Russian).

Yanko, V., 1990a. Stratigraphy and palaeogeography of marine Pleistocene and Holocene deposits of the southern seas of the USSR. Mem.Soc. Geol. Ital., vol. 44, p. 167-187 (In English).

Yanko, V., 1990b. Quaternary foraminifera of genus Ammonia of the Pontian-Caspian region. Paleontological Journal, no. 1, p. 18-26 (In Russian). 
Yanko, V., Ahmad, M., Kaminski, M., 1998. Morphological deformities of benthic foraminiferal tests in response to pollution by heavy metals: implications for pollution monitoring. Journal Foraminiferal Research, vol. 28, p. 177-200 (In English).

Yanko, V., Frolov, V., Motnenko, I., 1990. Foraminifera and lithology of the Karangat stratotype (Quaternary, Kerchenian Peninsula). Bull. Mosc. Soc. of Naturalists, vol. 65, no. 3, p. 83-97 (In Russian).

Yanko, V., Gramova, L., 1990. Stratigraphy of the Quaternary sediments of the Caucasian shelf and continental slope of the Black Sea based on microfauna-foraminifera and ostracoda. Sovetskaya Geologiya, no. 2, p. 60-72 (In Russian).

Yanko, V., Kennett, J., Koral, H., Kronfeld, J., 1999. Stable isotopic evidence from Holocene Sea of Marmara sediments for two-way watermass interchange between the Black Sea and the Mediterranean Sea. South African Journal of Sciences, vol. 95, no. 4, p. 201-204 (In English).

Yanko, V., Kondariuk, T.O., Kadurin, S.V., 2019. History of the geological development of the Black Sea northwest shelf in the Late Neopleistocene-Holocene. Collection of scientific works in the IGS of Ukraine, vol. 12, p. 135-158 (In Ukrainian).

Yanko, V., Kravchuk, A., Kulakova, I., 2017b. Meiobenthos of Methane Outlets of the Black Sea. Odessa, Phenix, 241 p. (In Russian).

Yanko, V., Troitskaya, T., 1987. Late Quaternary Foraminifera of the Black Sea. Moscow: Nauka, 111 p. (In Russian).

Zhamoida, A.I., 2004. Problems related to the international (standard) stratigraphic scale and its perfection, Stratigraphy and Geological Correlation, vol. 12, no 4, p. 321-330 (In English).

Zubakov, V.A., 1986. Global Climate Event of the Pleistocene. Leningrad: Gidrometeoizdat, 286 p. (In Russian).

Received January 15, 2020

B.В. Янко, д-р. геол.-мінерал. наук, проф., завідувач кафедри,

Кафедра загальної та морської геології,

Одеський національний університет імені I.I. Мечникова,

Шампанський просп., 2, Одеса, Україна, 65058

E-mail: valyan@onu.edu.ua

T.О. Кондарюк, доцент,

Кафедра загальної та морської геології,

Одеський національний університет імені I.I. Мечникова,

Шампанський просп., 2, Одеса, Україна, 65058

E-mail: tanya_kondaruk@ukr.net

\section{ПОХОДЖЕННЯ І СИСТЕМАТИКА НЕОПЛЕЙСТОЦЕН-ГОЛОЦЕНОВИХ БЕНТОСНИХ ФОРАМІНІФЕР ПОНТО-КАСПІЮ}

Стаття сфокусована на походженні та систематиці неоплейстоцен-голоценових форамініфер Понто-Каспію для їх подальшого використання в стратиграфії, геологічній історії та палеогеографічних реконструкціях, включаючи обмін води між сусідніми басейнами. Показано, що фауна каспійських форамініфер є мілководною, високоендемічною (92\%) з високим вмістом (61 \%) аглютинованих видів і підвидів. Азово-Чорноморська фауна форамініфер характеризується незначним ендемізмом (0,6 \%) лише на видовому та підвидовому рівнях, але великою кількістю (83 \%) середземноморських та атлантичних (переважно бореальних) форм. Усі азово-чорноморські форамініфери є мілководними, які зайшли в басейн, найімовірніше, через мілководну Бофорську або будь-яку іншу протоку, що з’єднувала Азово-Чорноморський басейн зі Середземним морем. Специфічний вигляд понтокаспійської фауни форамініфер полягає в тому, що вона складається 3 представників родин Ammoniidae i Elphididae. Це вказує на тенденцію формування форамініферової фауни з обмеженою кількістю шельфових родів південного генезису (Ammonia, Elphidium, Porosononion), характерних для південних ізольованих та напівізольованих морів. Низька кількість таксонів високого таксономічного рангу (рядів) $є$ наслідком низької солоності Понто-Каспію та його обмеженого зв'язку з відкритим океаном. Концепція походження неоплейстоцен-голоценової понтокаспійської фауни форамініфер припускає, що фауна Каспію успадковувалася від фауни Тетісу і Паратетісу. Вона утворилася переважно на еволюційній основі та без будь-якої залежності від азово-чорноморської фауни внаслідок тривалої ізоляції Каспію. Змішаний середземноморсько-атлантично-каспійський генезис чорноморської фауни форамініфер, іï̈ молодший порівняно з каспійською вік, а також значно менші еволюційні перетворення переважно в їі давньокаспійському компоненті серед родів Ammonia, Elphidium i Porosononion, поряд з високою мінливістю таксономічного складу внаслідок коливань рівня моря, відображає загальну тенденцію формування цієї фауни з обмеженою кількісті рядів (Ammodiscida, Astrorhizida, Ataxophragmiida, Buliminida, Lagenida, Miliolida, Rotaliida) в специфічних гідрологічних умовах внутрішніх і крайових морів.

Ключові слова: автохтони; алохтони; ендеміки; середземноморські іммігранти; каспійські іммігранти; релікти Параmemicy. 
Appendix 1. Classification of benthic foraminifera of the Caspian Sea region on their genesis

\begin{tabular}{|c|c|c|c|}
\hline \multirow{2}{*}{ Origin Species } & \multicolumn{2}{|c|}{ Autochtones } & \multirow{2}{*}{$\begin{array}{l}\text { Allochthons } \\
\text { (external) }\end{array}$} \\
\hline & $\begin{array}{l}\mathrm{New} \\
\text { (Eopleistocene) }\end{array}$ & $\begin{array}{c}\text { Newest } \\
\text { (Neopleistoceene-Holocene) }\end{array}$ & \\
\hline Ammonia caspica Stschedrina, $1975^{\star}$ & + & & \\
\hline Ammonia novoeuxinica Yanko, $1979^{*}$ & + & & \\
\hline Aubignyna mariei Margarel, 1970 & + & & \\
\hline Elphidium caspicum karadenizum Yanko, 1989* & + & & \\
\hline Haynesina ex gr. germanica (Ehrenberg, 1840)* & + & & \\
\hline Mayerella ex gr. brotzkajae (Mayer), 1968 & + & & \\
\hline Porosononion martkobi tschaudicus Yanko, $1989^{\star}$ & + & & \\
\hline Ammoscalaria verae Mayer, $1968^{*}$ & & + & \\
\hline Cornuspira minuscula (Mayer), $1968^{\star}$ & & + & \\
\hline Elphidium caspicum caspicum Yanko, 1989 & & + & \\
\hline Elphidium shochinae Mayer, $1968^{*}$ & & + & \\
\hline Haplophragmoides tenuicutis (Mayer) & & + & \\
\hline Hemisphaerammina sp. & & + & \\
\hline Mayerella brotzkajae (Mayer), $1968^{*}$ & & + & \\
\hline Miliolinella risilla Mayer, $1972^{*}$ & & + & \\
\hline Ovammina leptoderma Mayer & & + & \\
\hline Saccammina sp. & & + & \\
\hline Spiroplectinata perexilis (Mayer), 1968 & & + & \\
\hline Ammobaculites exiguus contractus Mayer, 1972 & & + & \\
\hline Entzia polystoma caspica (Mayer), 1968 & & + & \\
\hline Elphidium gunteri Cole, 1931 & & + & + \\
\hline Miliammina fusca (Brady, 1870)* & & + & + \\
\hline Trichochyalus aguajoi (Bermudez), 1935* & & + & \\
\hline Total & 8 & 14 & 3 \\
\hline
\end{tabular}

Note: ${ }^{\star}$ also present in the Black Sea region. 
Appendix 2. Classification of the Black Sea benthic foraminifera on their genesis

\begin{tabular}{|c|c|c|c|c|c|c|c|c|c|c|c|c|c|c|}
\hline \multirow[b]{4}{*}{ Genesis Species } & \multicolumn{2}{|c|}{ Autochthons } & \multicolumn{12}{|c|}{ Allochthons } \\
\hline & \multirow[b]{3}{*}{ 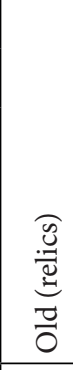 } & \multirow[b]{3}{*}{ 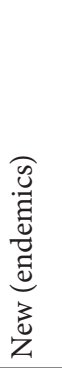 } & \multicolumn{2}{|c|}{ Caspian } & \multicolumn{10}{|c|}{ Mediterranean } \\
\hline & & & \multirow[b]{2}{*}{ 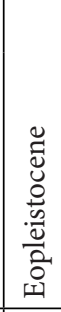 } & \multirow[b]{2}{*}{ 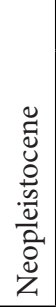 } & \multicolumn{6}{|c|}{ Neopleistocene } & \multicolumn{3}{|c|}{ Holocene } & \multirow[b]{2}{*}{ 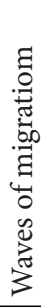 } \\
\hline & & & & & 芯 & 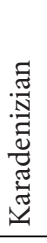 & 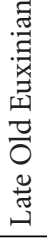 & 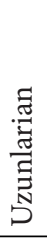 & 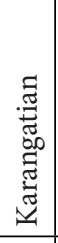 & 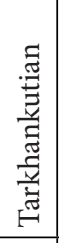 & 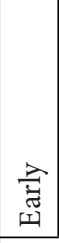 & 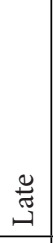 & & \\
\hline $\begin{array}{l}\text { Quinqueloculina delicatula Bogdanowich, } 1952 \\
\text { Quinqueloculina reussi (Bogdanowicz), } 1947 \\
\text { Triloculina angustioris (Bogdanowicz), } 1952\end{array}$ & $\begin{array}{l}+ \\
+ \\
+\end{array}$ & & & & & & & & $\begin{array}{l}+ \\
+ \\
+\end{array}$ & & & & & 4 \\
\hline $\begin{array}{l}\text { Ammonia caucasica Yanko, } 1990 \\
\text { Ammonia parasovica Stchedrina and Mayer, } 1975 \\
\text { Aubignyna suckumiensis Yanko, } 1989 \\
\text { Elphidium caspicum azovicum Yanko, } 1989 \\
\text { Elphidium caspicum uzunlarum Yanko, } 1989 \\
\text { Mayerella kolkhidica Yanko, } 1989 \\
\text { Porosononion martkobi ponticus Yanko, } 1989 \\
\text { Porosononion subgranosus mediterranicus Yanko, } 1989 \\
\text { Porosononion subgranosus pshadicus Yanko, } 1989 \\
\text { Porosononion submartkobi Yanko, } 1989 \\
\text { Psammmosphaera sp. } \\
\text { Ammonia caspica Stschedrina, } 1975 \\
\text { Elphidium caspicum karadenizum Yanko, } 1989 \\
\text { Florilus trochospiralis Mayer, 1968 } \\
\text { Ammobaculites exiguus contractus Mayer, } 1972 \\
\text { Ammonia novoeuxinica Yanko, } 1979 \\
\text { Cornuspira minuscula (Mayer), } 1968 \\
\text { Elphidium shochinae Mayer, 1968 } \\
\text { Mayerella brotzkajae (Mayer), } 1968 \\
\text { Miliammina fusca (Brady, 1870) } \\
\text { Miliolinella risilla Mayer, 1972 } \\
\text { Porosononion martkobi tschaudicus Yanko, } 1989 \\
\text { Trichochyalus aguajoi (Bermudez), } 1935 \\
\text { Quinqueloculina oblonga (Montagu), } 1803 \\
\text { Quinqueloculina seminulum (Linne), } 1767\end{array}$ & & $\begin{array}{l}+ \\
+ \\
+ \\
+ \\
+ \\
+ \\
+ \\
+ \\
+ \\
+ \\
+ \\
+\end{array}$ & $\begin{array}{l}+ \\
+ \\
+\end{array}$ & 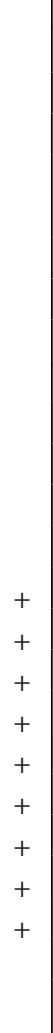 & 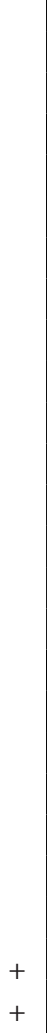 & & & & & & & & & \\
\hline $\begin{array}{l}\text { Ammonia tepida (Cushman), } 1928 \\
\text { Cibicides mckannai Galloway and Wiesler, } 1927 \\
\text { Fissurina sp., in Yanko, } 1989 \\
\text { Nonion matagordanus Kornfeld, in Cushman, } 1939 \\
\text { Quinqueloculina inflata (d'Orbigny), } 1826 \\
\text { Quinqueloculina vulgaris d'Orbigny, } 1826\end{array}$ & & & & & & $\begin{array}{l}+ \\
+ \\
+ \\
+ \\
+ \\
+\end{array}$ & & & & & & & & $1^{\text {st }}$ \\
\hline $\begin{array}{l}\text { Florilus cf. atlanticum (Cushman), in Yanko, } 1989 \\
\text { Oolina sp., in Yanko, } 1989 \\
\text { Parafissurina dzemetinica Yanko, } 1974\end{array}$ & & & & & & & $\begin{array}{l}+ \\
+ \\
+\end{array}$ & & & & & & & $2^{\mathrm{d}}$ \\
\hline $\begin{array}{l}\text { Aubignyna mariei Margarel, } 1970 \\
\text { Aubignyna perlucida (Herron-Allen and Earland), } 1913 \\
\text { Quinqueloculina consobrina (d'Orbigny), } 1846 \\
\text { Quinqueloculina milletti (Wiesner), } 1912 \\
\text { Rosalina catesbyana d'Orbigny, } 1839\end{array}$ & & & & & & & & $\begin{array}{l}+ \\
+ \\
+ \\
+ \\
+\end{array}$ & & & & & & $3^{\mathrm{d}}$ \\
\hline
\end{tabular}


Continuated of Appendix 2

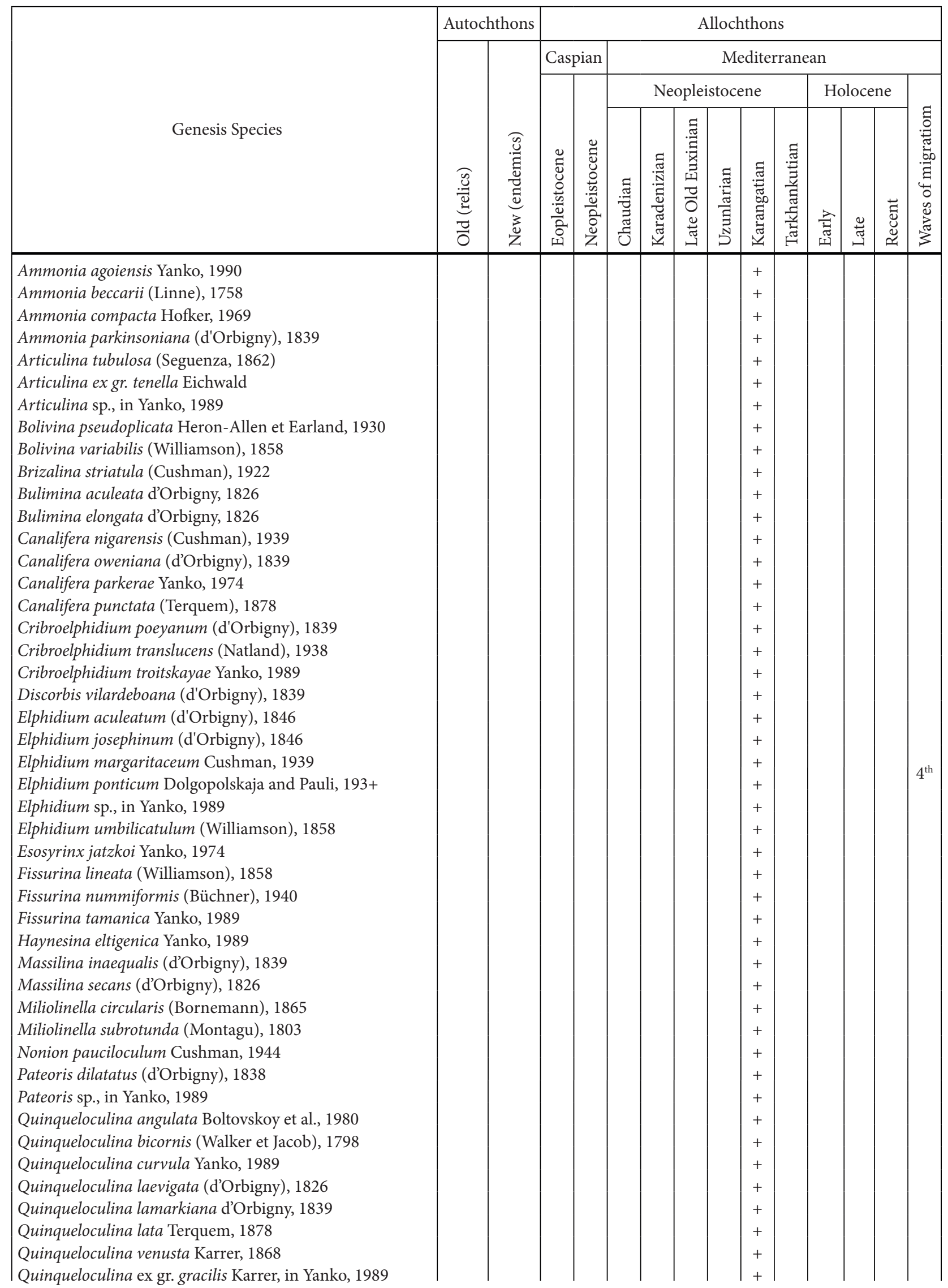


Continuated of Appendix 2

\begin{tabular}{|c|c|c|c|c|c|c|c|c|c|c|c|c|c|c|}
\hline \multirow[b]{4}{*}{ Genesis Species } & \multicolumn{2}{|c|}{ Autochthons } & \multicolumn{12}{|c|}{ Allochthons } \\
\hline & \multirow[b]{3}{*}{ 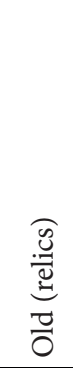 } & \multirow[b]{3}{*}{ 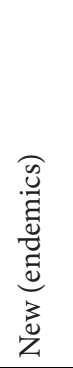 } & \multicolumn{2}{|c|}{ Caspian } & \multicolumn{10}{|c|}{ Mediterranean } \\
\hline & & & \multirow[b]{2}{*}{ 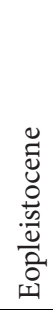 } & \multirow[b]{2}{*}{ 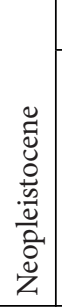 } & \multicolumn{6}{|c|}{ Neopleistocene } & \multicolumn{3}{|c|}{ Holocene } & \multirow[b]{2}{*}{ 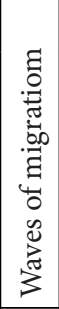 } \\
\hline & & & & & 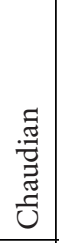 & 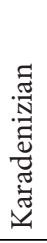 & 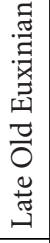 & 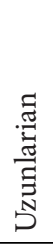 & 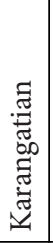 & 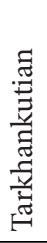 & 矛 & $x^{2}$ & 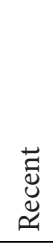 & \\
\hline $\begin{array}{l}\text { Sigmella distorta (Phleger et Parker), 195+ } \\
\text { Sigmella tenuis (Czjzek), } 1848 \\
\text { Triloculina sp. 2, in Yanko, } 1989\end{array}$ & & & & & & & & & $\begin{array}{l}+ \\
+ \\
+\end{array}$ & & & & & $4^{\text {th }}$ \\
\hline Haynesina anglica (Murray), 1965 & & & & & & & & & & + & & & & $5^{\text {th }}$ \\
\hline $\begin{array}{l}\text { Cribroelphidium percursum Yanko, } 1974 \\
\text { Discammina imperspica Yanko, } 1974 \\
\text { Eggerelloides scaber (Williamson, 1858) } \\
\text { Fissurina fragilis Troitskaya, 1987 } \\
\text { Fissurina lucida (Williamson), } 1858 \\
\text { Fissurina porrecta Troitskaya, } 1987\end{array}$ & & & & & & & & & & & $\begin{array}{l}+ \\
+ \\
+ \\
+ \\
+ \\
+\end{array}$ & & & $6^{\text {th }}$ \\
\hline $\begin{array}{l}\text { Acervulina ex gr. adchaerens Schultze } \\
\text { Ammobaculites ponticus Michalevich, } 1968 \\
\text { Ammonia ammoniformis (d'Orbigny), } 1826 \\
\text { Brizalina spathulata (Williamson), } 1858 \\
\text { Bolivina doniezi Cushman et Wickenden, } 1929 \\
\text { Bolivina ex gr. dilatata Reuss, in Yanko, } 1989 \\
\text { Canalifera earlandi (Cushman), } 1936 \\
\text { Canalifera ex gr. verriculata (Brady) } \\
\text { Cibicides dispars (d'Orbigny), 1838 } \\
\text { Cibicides lobatulus (Walker and Jacob), } 1798 \\
\text { Cornuspira planorbis Shultze, } 1854 \\
\text { Entolingulina deplanata Yanko, } 1974 \\
\text { Esosyrinx praelongus (Terquem), 1878 } \\
\text { Fissurina fabaria Troitskaya, 1987 } \\
\text { Fissurina solida Seguenza, 1862 } \\
\text { Guttulina lactea (Walker and Jacob), } 1798 \\
\text { Lagena sp., in Yanko, 1989 } \\
\text { Lagena striata (d'Orbigny), 1839 } \\
\text { Lagena vulgaris Williamson, } 1858 \\
\text { Laryngosigma williamsoni (Terquem), } 1878 \\
\text { Miliolinella selene (Karrer), 1868 } \\
\text { Miliolinella elongata Kruit } \\
\text { Oolina squamosa (Montagu), } 1803 \\
\text { Orthomorphina calomorpha (Reuss), } 1866 \\
\text { Orthomorphina drammenensis Feyling-Hanssen, } 1964 \\
\text { Orthomorphina filiformis (d'Orbigny), } 1826 \\
\text { Parafissurina aventricosa McCulloch, } 1968 \\
\text { Parafissurina ex gr. lateralis Cushman } \\
\text { Proteonella atlantica (Cushman), 1944 } \\
\text { Pyrgo elongata (d'Orbigny), 1826 } \\
\text { Rosalina sp., in Yanko, } 1989 \\
\text { Rotaliammina ochracea (Williamson), } 1858 \\
\text { Siphonaperta agglutinans (d'Orbigny) } \\
\text { Trifarina angulosa (Williamon), 1858 }\end{array}$ & & & & & & & & & & & & $\begin{array}{l}+ \\
+ \\
+ \\
+ \\
+ \\
+ \\
+ \\
+ \\
+ \\
+ \\
+ \\
+ \\
+ \\
+ \\
+ \\
+ \\
+ \\
+ \\
+ \\
+ \\
+ \\
+ \\
+ \\
+ \\
+ \\
+ \\
+ \\
+ \\
+ \\
+ \\
+ \\
+ \\
+ \\
+ \\
+ \\
+\end{array}$ & & $7^{\text {th }}$ \\
\hline
\end{tabular}


The End Appendix 2

\begin{tabular}{|c|c|c|c|c|c|c|c|c|c|c|c|c|c|c|}
\hline \multirow[b]{4}{*}{ Genesis Species } & \multicolumn{2}{|c|}{ Autochthons } & \multicolumn{12}{|c|}{ Allochthons } \\
\hline & \multirow[b]{3}{*}{ 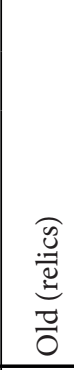 } & \multirow[b]{3}{*}{ 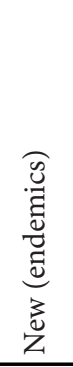 } & \multicolumn{2}{|c|}{ Caspian } & \multicolumn{10}{|c|}{ Mediterranean } \\
\hline & & & & & \multicolumn{6}{|c|}{ Neopleistocene } & \multicolumn{3}{|c|}{ Holocene } & \multirow[b]{2}{*}{ 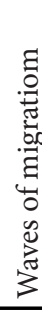 } \\
\hline & & & 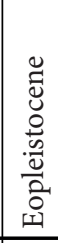 & 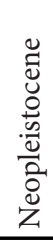 & 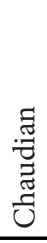 & 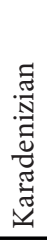 & 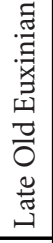 & 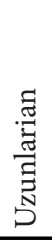 & 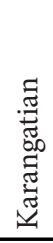 & 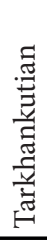 & . & $\stackrel{\stackrel{\Xi}{ت}}{ت}$ & 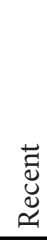 & \\
\hline $\begin{array}{l}\text { Ammoscalaria sp., in Yanko, } 1989 \\
\text { Brizalina ex gr. danvillensis (Howe et Wallace), } 1932 \\
\text { Discorbis bertheloti (d'Orbigny), } 1839 \\
\text { Discorbis sp., in Yanko, } 1989 \\
\text { Esosyrinx undulosus (Terquem), } 1878 \\
\text { Esosyrinx sp., in Yanko, } 1989 \\
\text { Gavelinopsis sp., in Yanko, } 1989 \\
\text { Glandulina sp., in Yanko, } 1989 \\
\text { Heronallenia chasteri (Herron-Allen and Earland), 19+3 } \\
\text { Lagena quadrilatera quadrilatera Earland, } 1934 \\
\text { Lagena semistriata (Williamson), } 1858 \\
\text { Planorbulinella mediterranensis d'Orbigny, } 1826 \\
\text { Pyrgo fisheri (Schlumberger), } 189+ \\
\text { Sigmella sp., in Yanko, } 1989 \\
\text { Textularia conica d'Orbigny, } 1839\end{array}$ & & & & & & & & & & & & & $\begin{array}{l}+ \\
+ \\
+ \\
+ \\
+ \\
+ \\
+ \\
+ \\
+ \\
+ \\
+ \\
+ \\
+ \\
+ \\
+\end{array}$ & $8^{\text {th }}$ \\
\hline Total & 3 & 10 & 3 & 9 & 2 & 6 & 3 & 5 & 52 & 1 & 6 & 34 & 15 & \\
\hline
\end{tabular}

